\title{
RECOGNITION AND ENFORCEMENT OF JUDGMENTS: RECENT DEVELOPMENTS
}

Pedro A. DE MIGUEL ASENSIO *

Published in:

Research Handbook on Cross-border Enforcement of Intellectual Property, Edward Elgar, Cheltenham, 2014, (ed. P. Torremans) pp. 469-497

* Catedrático de Derecho internacional privado

Facultad de Derecho

Universidad Complutense de Madrid

E- 28040 MADRID

pdmigue@ucm.es 


\title{
RECOGNITION AND ENFORCEMENT OF JUDGMENTS: RECENT DEVELOPMENTS
}

\author{
PEDRO A. DE MIGUEL ASENSIO*
}

\section{Introduction}

Recognition and enforcement of foreign judgments is of great importance for an effective protection of intellectual property rights in the international sphere ${ }^{1}$. Due to the separation of national judicial systems, the effects of a judgment are in principle limited to the territory of the country whose court rendered it. Therefore, a foreign judgment must be recognized or declared enforceable in the local forum in order to produce its typical effects as a judgment, such as res judicata, beyond the country where it was rendered. The trend to restrict the scope of exclusive jurisdiction in intellectual property matters favours the cross-border adjudication of disputes in this area, and strengthens the practical significance of recognition and enforcement of judgments.

Enforcement abroad may be decisive to ensure the authority of an injunction ordering a party to desist from an infringement in the territory of several countries since injunctions are typically to be enforced in the country of protection of an intellectual

* Chaired Professor at the Complutense University of Madrid. This contribution was supported by research project DER 2012-34086 (MEC). The author is member of the European Max Planck Group on Conflict of Laws in Intellectual Property (CLIP) and co-rapporteur of the Committee on Intellectual Property and Private International Law of the International Law Association. All webpages cited have been last accessed on 11 October 2013.

\footnotetext{
${ }^{1}$ See, in more detail and with references, Pedro A. De Miguel Asensio, "Recognition and Enforcement of Judgments in Intellectual Property Litigation: The CLIP Principles”, in Jürgen Basedow, Toshiyki Kono and Axel Metzger (eds.), Intellectual Property in the Global Arena - Jurisdiction, Applicable Law, and the Recognition of Judgments in Europe, Japan and the US, Mohr Siebeck (2010), pp. 239-292; and Pedro A. De Miguel Asensio, "Part 4: Recognition and Enforcement”, Conflict of Laws in Intellectual Property (The CLIP Principles and Commentary), OUP (2013), pp. 388-468.
} 
property right. Money judgments against defendants without sufficient assets in the forum State also raise special needs. It becomes necessary to pursue additional litigation in a country where the defendant has assets unless the original judgment can be enforced in such country. In addition, recognition of a foreign judgment is needed to prevent subsequent litigation in a different forum. Reliance on the res judicata effect of a foreign judgment is necessary to prevent the losing party from bringing new proceedings involving the same cause of action and between the same parties in the courts of another state. Recognition ensures the protection of rights acquired under a foreign system, which is especially important in a context of increasing globalization.

The present contribution focuses on certain recent developments in this field. Although progress in establishing closer international cooperation remains limited, the increasing awareness of the importance of cross-border recognition and enforcement of judgments in international disputes concerned with intellectual property rights, has led to significant attention being paid to these issues in proposals for legislative reform drafted in recent years. Some sets of principles and their commentaries have become a basic reference in debates concerning the application of international and domestic instruments in this area and the evolution of national, regional and international legislation with a view to a more effective adjudication of cross-border disputes respectful to all interests involved ${ }^{2}$. In particular, attention has to be paid to the provisions on recognition and enforcement of judgments of the "Principles Governing Jurisdiction, Choice of Law, and Judgments in Transnational Disputes”, adopted in 2008 by the American Law Institute (ALI Principles) ${ }^{3}$; the "Principles for Conflict of Laws in Intellectual Property” of 2011, prepared by the European Max Planck Group on Conflict of Laws in Intellectual Property (CLIP Principles) ${ }^{4}$; and two other sets of principles drafted in Asia ${ }^{5}$. The interest in developing further international cooperation

\footnotetext{
${ }^{2}$ See, e.g., Stefania Bariatti (ed), Litigating Intellectual Property Rights Disputes Cross-Border: EU Regulations, ALI Principles, CLIP Project CEDAM (2010).

${ }^{3}$ American Law Institute, Intellectual Property: Principles Governing Jurisdiction, Choice of Law and Judgments in Transnational Disputes, St Paul, ALI Publishers (2008).

4 European Max Planck Group on Conflict of Laws in Intellectual Property, Conflict of Laws in Intellectual Property (Text and Commentary), Oxford, OUP (2013).

5 The Japanese Transparency Proposal on Jurisdiction, Choice of Law, Recognition and Enforcement of Foreign Judgments in Intellectual Property was adopted in October 2009 (see Jürgen Basedow, Toshiyki Kono and Axel Metzger, supra, note 1, pp. 394-402) (Transparency Proposal). An
} 
in this field at a global scale, building upon those previous initiatives, has been acknowledged by the International Law Association (ILA) ${ }^{6}$.

Other current developments concerning international or European legislation in the field of recognition and enforcement of judgments in general are also particularly relevant in this context, due to the traditional absence of specific provisions on the enforcement of judgments in intellectual property matters. Therefore, both the debates on the efforts at the Hague Conference to draft a global instrument covering recognition and enforcement of judgments, and the reform of the common EU rules on recognition and enforcement are of interest. In particular, it is noteworthy that the basic EU instrument on recognition and enforcement of judgments, governing also intellectual property matters, has recently been amended. Regulation (EU) No 1215/2012 of 12 December 2012 on jurisdiction and the recognition and enforcement of judgments in civil and commercial matters (recast) (Brussels I recast) ${ }^{7}$ shall repeal Regulation (EC) No 44/2001 (Brussels I Regulation) ${ }^{8}$. The new Regulation shall apply from 10 January 2015 and one of its basic elements of reform concerns the procedure for recognition and enforcement of judgments. The fact that the Brussels I Regulation (and its recast) covers, among other matters, litigation in the area of intellectual property rights, has been recently illustrated by the need to address the relationship between the Brussels I Regulation (recast), including its provisions on recognition and enforcement ${ }^{9}$, and the Agreement on a Unified Patent Court or "UPC Agreement"10.

\section{Sources of regulation}

initiative started at the Waseda University led to the adoption in October to 2010 of an additional set of Principles as a Joint Proposal Drafted by Members of the Private International Law Association of Korea and Japan ((2011) The Quarterly Review of Corporation Law and Society, pp. 112-163) (Joint Korean and Japanese Proposal).

6 The International Law Association, "Intellectual Property and Private International Law. Committee Report”, Report of the Seventy-Fifth Conference, London, 2012, pp. 791-813.

${ }^{7}$ OJ 2012 L 351/1.

${ }^{8}$ Regulation (EC) no. 44/2001 of 22 December 2000 on jurisdiction, and the recognition and enforcement of judgments in civil and commercial matters, OJ 2001 L 12/1.

${ }^{9}$ See Proposal for a Regulation amending Regulation (EU) No 1215/2012 on jurisdiction and the recognition and enforcement of judgments in civil and commercial matters, COM(2013) 554 final, 26.7.2013

${ }^{10}$ OJ 2013 C 175/1. 


\section{A. International instruments}

The attempts to create international instruments covering the recognition and enforcement of judgments resulting from disputes relating to intellectual property have not been successful beyond regional organizations ${ }^{11}$. Due to the limitations of the existing conventions and the lack of global agreements, the applicable rules on recognition and enforcement usually depend on the law of the country where the enforcement is sought. The multilateral treaties that establish the basic international framework concerning intellectual property, such as the TRIPS Agreement ${ }^{12}$ and the WIPO Treaties, do not deal with cross-border recognition and enforcement of judgments. Even if enforcement measures receive significant attention in some of these instruments, their focus rests on domestic enforcement, and no harmonization is provided for concerning recognition and enforcement of foreign judgments.

On the other hand, progress in the field of international judicial cooperation in civil matters, has resulted in the conclusion of a significant number of international conventions dealing with recognition and enforcement of foreign judgments. However, the overall impact of those conventions on intellectual property litigation remains rather limited. There are no particular recognition conventions in relation to intellectual property matters. Notwithstanding this fact, the scope of application of some international conventions covers judgments resulting from intellectual property disputes. That is typically the case with regard to bilateral conventions on recognition and enforcement of judgments concerning civil and commercial matters in general, unless otherwise provided in the respective convention. Even though the existence of a network of bilateral conventions may be relevant in some national legal systems, from a global perspective the practical repercussion of general conventions is small since there is no general multilateral convention that has achieved significant international acceptance. Furthermore, international conventions and regional instruments on recognition of judgments are usually subject to reciprocity, and hence they only apply to decisions adopted by the courts of other contracting states

${ }^{11}$ On these issues, see Pedro A. De Miguel Asensio, supra, note 1, with references.

12 Agreement on Trade-Related Aspects of Intellectual Property Rights of 15 April 1994, 1869 UNTS 299. 
Noteworthy in this context is the failure of the negotiations at the Hague Conference during the 1990s on a proposed convention on Jurisdiction and Foreign Judgments in Civil and Commercial Matters, whose main result was the Preliminary Draft Convention on Jurisdiction and Foreign Judgments in Civil and Commercial Matters of 30 October 1999 and the revised Draft of $2001^{13}$. Later the scope of the negotiations was restricted, leading to the conclusion on 30 June 2005 of the Convention on Choice of Court Agreements ${ }^{14}$. Its scope of application covers only choice-of-court clauses in business-to-business cases and does not contain rules on jurisdiction for specific subject matters such as infringement of intellectual property rights. Its provisions on recognition and enforcement apply only to judgments given by a court of a contracting state designated in an exclusive choice-of-court agreement (Art. 8.1).

The Hague Conference has recently reopened the discussions on a possible general instrument "relating to recognition and enforcement of judgments, including jurisdictional filters” ${ }^{15}$. However, the scope of the project -even whether intellectual property matters would be covered- remains uncertain, and its progress faces significant obstacles $^{16}$.

\section{B. European Union Law}

The EU has adopted no specific instrument on the recognition and enforcement of foreign judgments regarding intellectual property matters. In particular, Directive 2004/48/EC of 29 April 2004 on the enforcement of intellectual property rights ${ }^{17}$, does not deal with cross-border recognition and enforcement of judgments ${ }^{18}$. However, significant uniformity has been achieved within the EU by means of the application of

\footnotetext{
${ }^{13}$ http://www.hcch.net.

${ }^{14}$ See http://www.hcch.net. As of 30 September 2013 the Convention is not yet in force.

15 See Hague Conference on Private International Law, 'Conclusions and Recommendations Adopted by the Council on General Affairs and Policy’ (17-20 April 2012), http://www.hcch.net.

${ }^{16}$ Although focusing on jurisdiction, see Ronald A. Brand, 'Jurisdictional Developments and the New Hague Judgments Project', Permanent Bureau of the HccH (ed.), A Commitment to Private International Law (Essays in Honour of Hans Van Loon) Intersentia ( 2013), pp. 89-99.

17 OJ 2004 L 157/45.

18 See Costanza Honorati, 'Il riconoscimento delle decisioni in materia di proprietà intellettuale', in Andrea Giussani (ed), Il proceso industriale Giappichelli (2012) p. 485
} 
the general rules on recognition and enforcement of judgments in civil and commercial matters, initially established in the 1968 Brussels Convention ${ }^{19}$, and later contained in the Brussels I Regulation. The provisions on recognition and enforcement of the Brussels I Regulation apply to judgments relating to intellectual property matters ${ }^{20}$.

Even in those areas where unitary intellectual property rights have been created in the EU by means of specific regulations, mutual recognition and enforcement of judgments concerning such rights remain governed by the Brussels I Regulation. Unitary rights are governed by uniform EU rules directly applicable in all Member States, such as Regulation (EC) No 207/2009 of 26 February 2009 on the Community trade mark ${ }^{21}$ and Regulation (EC) No 6/2002 of 12 December 2001 on Community designs ${ }^{22}$. These two instruments contain some provisions on international jurisdiction that prevail over the Brussels I Regulation ${ }^{23}$. By contrast, they lack rules on recognition and enforcement of judgments in civil matters, that remain governed solely by the Brussels I Regulation ${ }^{24}$.

Notwithstanding this, the common EU recognition and enforcement rules of the Brussels I Regulation and its recast are only applicable to judgments given by a court of another Member State. Hence, there is no uniform approach to the recognition of judgments rendered in third countries. The current EU legislation does not ensure equal treatment and effects to third-country judgments throughout the $\mathrm{EU}$ because the recognition and enforcement of such judgments remain outside the scope of application of the Brussels I Regulation and are subject in each EU Member State to that state's own domestic rules. The review of the Brussels I Regulation has confirmed this situation, since the Brussels I recast has not introduced common rules on the recognition and enforcement of third-state judgments in the EU. In this context, future developments in this field at the Hague Conference have become particularly relevant

\footnotetext{
${ }^{19}$ Consolidated version in OJ 1998 C 27/1.

20 See, eg, Dário Moura Vicente, 'La propriété intellectuelle en droit international privé' (2008) 335 Recueil des Cours, p. 420; and James Fawcett and Paul Torremans, Intellectual Property and Private International Law OUP (2nd ed, 2011), p. 946.

${ }^{21}$ OJ 2009 L 78/1.

22 OJ 2002 L 3/1.

${ }^{23}$ Arts. 94 et seq Regulation (EC) No 207/2009 and arts. 79 et seq Regulation (EC) No 6/2002.

${ }^{24}$ However, concerning provisional measures, see art. 103.2 Regulation (EC) No 207/2009 and art. 90.3 Regulation (EC) No 6/2002.
} 
from the European perspective as an alternative or a supplement to the establishment of a common EU regime on the effects of third-state judgments ${ }^{25}$. Regarding the conclusion of international conventions, it is important to note that after the 2006 ECJ Opinion $^{26}$ concerning the Lugano Convention ${ }^{27}$ and in light of Articles 3(2) and 216 $\mathrm{TFEU}^{28}$, an expansive view of the scope of the EU external exclusive competence prevails in the practice of the EU institutions. According to this view, the Union has exclusive external competence to conclude international conventions on the recognition and enforcement of foreign judgments in matters regulated in an EU instrument, such as judgments on intellectual property disputes covered by the Brussels I Regulation. However, in contrast with the role played by bilateral conventions on recognition and enforcement in the Private International Law systems of some Member States, the EU has so far not been active in the negotiation of such agreements with third States.

The need to amend the Brussels I recast with a view to ensure its coordination with the UPC Agreement has now been addressed by the Commission Proposal of July 2013 for a Regulation amending Regulation (EU) No 1215/2012 on jurisdiction and the recognition and enforcement of judgments in civil and commercial matters ${ }^{29}$. Only its provisions concerning recognition and enforcement are relevant for these purposes. First, the express clarification that the Unified Patent Court is a 'court' within the meaning of the Brussels I Regulation (recast) is relevant to consider that judgments given by the envisaged common court should be recognized and enforced in accordance with the Brussels I recast. Furthermore, the proposed amendment addresses the operation of the rules on recognition and enforcement in the relations between Member States which are and Member States which are not Contracting Parties to the UPC Agreement. This Agreement regulates the enforcement of the judgments of the UPC in the Contracting Member States. Article 82 UPC Agreement lays down that decisions of

\footnotetext{
${ }^{25}$ For instance, the European Parliament urged the Commission to use its best endeavours at the Hague Conference to revive the project for an international judgments convention, see Resolution of 23 November 2010 on civil law, commercial law, family law and private international law aspects of the Action Plan Implementing the Stockholm Programme (2010/2080(INI)).

${ }^{26}$ The parallel Lugano Convention of 16 September 1988 extended the application of the rules of the 1968 Brussels Convention to other European States. Its successor is the Lugano Convention of 30 October 2007, OJ 2007 L 339/1.

${ }^{27}$ ECJ Opinion 1/03 of 7 February 2006.

28 Treaty on the Functioning of the Euopean Union, consolidated version OJ 2008 C 115/47.

${ }^{29}$ See supra, note 9.
} 
the Court shall be enforceable in any Contracting State. Moreover, pursuant to Article 34 UPC Agreement: "Decisions of the Court shall cover, in the case of a European patent, the territory of those Contracting Member States for which the European patent has effect”.

The proposed amendment to the Brussels I recast establishes that the Regulation applies to the recognition and enforcement of judgments given by the UPC which need to be recognised and enforced in Member States which are not Contracting Parties to the UPC. It also envisages the application of the Brussels I recast to judgments given by the courts of Member States which are not Contracting Parties to the UPC which need to be recognised and enforced in Member States Contracting Parties to such Agreement.

\section{Diversity of national regimes}

Due to the limited significance of international instruments, recognition and enforcement of foreign judgments relating to intellectual property remains mainly regulated at national level, where no regional schemes have been developed or to the extent that such regimes do not apply. National regimes on recognition and enforcement differ significantly across the world in many respects. For instance, they differ as to the role of reciprocity as a basic tool determining if recognition of judgments from of a given country is possible or not ${ }^{30}$. Differences also may be found with regard to the grounds for non-recognition and enforcement of foreign judgments.

Moreover, the limits regarding the possibility to enforce certain judgments, such as preliminary measures and non-monetary judgments, may differ significantly. The divergent understanding of some shared controls, such as procedural and substantive public policy, reinforce the significant disparity in this area, that becomes a source of uncertainty and an obstacle hindering efficient resolution of international intellectual property disputes.

\footnotetext{
${ }^{30}$ For example, concerning the traditional importance of reciprocity in the Chinese system in sharp contrast with the current situation in many other national systems, see Wenliang Zhang, 'Recognition and Enforcement of Foreign Judgments in China: A Call for Special Attention to Both the Due Service Requirement and the Principle of Reciprocity’, (2013) Chinese Journal of International Law, vol. 12, , pp. 143-174.
} 


\section{Recognition and enforcement of judgments in recent reform proposals}

Given the significance of recognition and enforcement provisions and the importance of developing uniform rules, this area of international civil procedure has become an essential part in a number of recent projects aimed at improving international litigation on intellectual property rights. In this context, the 2008 ALI Principles devote Part IV to "Recognition and Enforcement of Foreign Judgments in Transnational Cases”; also Part 4 of the CLIP Principles seeks to facilitate recognition and enforcement of foreign judgments providing adequate safeguards; Articles 401 to 404 form the Section on 'Recognition and Enforcement of Foreign Judgments' in the 2009 Japanese Transparency Proposal; and Part IV of the 2010 Joint Proposal Drafted by Members of the Private International Law Association of Korea and Japan deals also with 'Recognition and Enforcement of Foreign Judgments'.

Although some differences in approach are significant, the comparison of these four sets of principles basically shows that in general terms they lead to similar results, favouring the recognition and enforcement of judgments ${ }^{31}$. It seems a shared conviction that enhancing the enforceability of foreign judgments and promoting international judicial cooperation are convenient to achieve a better protection of legitimate interests of right holders and users of intellectual property in the current global context. This progressive approach is illustrated by the recourse to a broad definition of judgment as the object of recognition and enforcement, including non-monetary and default judgments, as well as provisional measures, and the view that foreign judgments subject to appeal may be, under certain circumstances, recognised and enforced in the requested State ${ }^{32}$.

${ }^{31}$ See Toshiyuki Kono, Nozomi Tada and Miho Shin, 'Recognition and Enforcement of Foreign Judgments Relating to IP Rights and Unfair Competition' in Jürgen Basedow, Toshiyki Kono and Axel Metzger (eds.), Intellectual Property in the Global Arena - Jurisdiction, Applicable Law, and the Recognition of Judgments in Europe, Japan and the US, Mohr Siebeck (2010), pp. 293-340; Toshiyuki Kono and Paulius Jurcys, 'General Report' in Toshiyuki Kono (ed), Intellectual Property and Private International Law: Comparative Perspectives Hart (2012), pp. 188-211; and Benedetta Ubertazzi, 'Recognition and Enforcement of Foreign Judgments in Intellectual Property: a Comparison for the International Law Association', 3 (2012) JIPITEC, 3, 306.

${ }^{32}$ In the European context, the ECJ has stressed the significance of a broad understanding of the concept of judgment to favour mutual recognition and enforcement. Therefore, the Court has established that in the framework of the Brussels I Regulation such concept "covers 'any' judgment given by a court 
The trend to restrict the scope of exclusive jurisdiction to certain disputes concerning the validity or registration of an intellectual property right, and the progressive acceptance of similar grounds of jurisdiction in other areas such as infringement claims, favours the application of similar standards with respect to verification of jurisdiction as a ground for non-recognition. A restrictive understanding also prevails with regard to the overall design of the possible grounds of non-recognition and their interpretation. This tendency is illustrated by the abandonment of reciprocity as a condition for recognition and enforcement, the exclusion of substantive review, and the provisions on procedural and substantive public policy, including the limited circumstances under which it is possible to refuse recognition and enforcement of a judgment awarding noncompensatory damages.

\section{Types of judgments: monetary judgments, injunctions and default judgments}

Acceptance of a broad concept of judgment as the object of recognition and enforcement results in overcoming the traditional reluctance of certain legal systems concerning some types of foreign judgments, in particular non-monetary judgments, default judgments and provisional measures.

The distinction between monetary and non-monetary judgments has important implications regarding the means of enforcement. In the context of intellectual property litigation, both monetary and non-monetary judgments are very common ${ }^{33}$. Money judgments are usually the result of the authority granted to the courts to order the infringer to pay damages to the rightholder. Due to the different approaches on punitive damages, among the specific issues raised by money judgments are those concerning

of a Member State, without any distinction being drawn according to the content of the judgment in question, which means that, in principle, that concept also comprises a judgment by which a court of a Member State declines jurisdiction on the basis of a jurisdiction clause”, ECJ Judgment of 15 November 2012, C-456/11, Gothaer, [2013] 2 W.L.R. 520; [2013] C.E.C. 793; [2013] I.L.Pr. 7, para. 23; furthermore, the concept is not limited to decisions which terminate a dispute in whole or in part, but also applies to provisional or interlocutory decisions, see Judgments of 18 October 2011, C-406/09, Realchemie Nederland, [2012] Bus. L.R. 1825; [2012] C.E.C. 449; [2012] I.L.Pr. 1, para. 38; and 14 October 2004, C-39/02 Mcrsk Olie \& Gas, [2004] E.C.R. I-9657, para. 46.

${ }^{33}$ See Pedro A. De Miguel Asensio, supra, note 1, with references. 
the cross-border implications of judgments awarding non compensatory damages, and its significance in the context of substantive public policy. Typical non-money judgments include injunctions prohibiting the production or marketing of goods or the use of protected subject matter, orders to surrender and deliver infringing goods, or other orders for specific performance. Non-money judgments also comprise merely declaratory judgments, including negative declarations.

Traditionally, some legal systems, especially in the common law world, have been reluctant to admit the possibility of enforcing foreign non-money judgments, since enforceability of foreign in personam judgments under the common law was considered limited to judgments for a fixed or ascertainable sum of money. However, in most jurisdictions, including the UK, Australia, and the US, a clear trend to disregard that traditional view prevails, and it is also widely accepted that the common law should be extended to make possible the enforcement of foreign non-money judgments ${ }^{34}$. Compared to judgments for a fixed sum of money, the recognition and enforcement of foreign non-money judgments may raise specific difficulties and demand additional involvement by the authorities of the destination country. That is especially the case when injunctive relief is ordered.

With respect to intellectual property litigation it can be noted that the TRIPS Agreement establishes a comprehensive set of remedies (Articles 45-48). International harmonization favours that the remedies established in most jurisdictions are rather similar. Difficulties may arise in cases in which the kind of relief granted in the foreign judgment is unknown or is not available in the country where recognition or enforcement is sought. To overcome possible difficulties, it seems appropriate to grant a remedy available in the enforcing country that is functionally or substantially equivalent to the one awarded in the foreign judgment because it fulfils the object sought by the foreign order. ${ }^{35}$ In this connection, it is noteworthy that in the light of the diversity of enforcement measures existing under national procedural laws, article 54 Regulation

\footnotetext{
${ }^{34}$ See the decision by the Supreme Court of Canada in Pro Swing Inc. v. Elta Golf Inc., [2006] 2 S.C.R. 612, 2006 SCC 52, concluding that the "time is ripe to change the common law rule against the enforcement of foreign non-monetary judgments” (para. 64).

35 Richard F. Oppong, 'Enforcing Foreign Non-Money Judgments: An Examination of Some Recent Developments in Canada and Beyond’, (2006) 39 U.B.C. L. Rev. 258, at 268.
} 
(EU) No 1215/2012 (Brussels I recast) allows for an adaptation based on a functional equivalence principle. Pursuant to this provision, where a judgment contains a measure or order which is not known in the law of the Member State addressed, that measure or order should, to the extent possible, be adapted to one which, under the law of that State, has equivalent effects attached to it and pursues similar aims and interests. Article 54 further clarifies that such adaptation shall not result in effects going beyond those provided for in the law of country of origin.

The requirements under which injunctions, preliminary or permanent, are issued and the sort of relief granted depend on the law applicable to the infringement by the rendering court, and significant divergences may exist as to those requirements that evolve in the national legal systems. ${ }^{36}$ In this context, the content of the foreign injunction, construed under a foreign law, as to when, where, and how the defendant must do or abstain from doing something may require interpretation or adaptation to new circumstances (for instance, as a result of succession of parties or modifications of corporation scheme after the judgment was rendered). The courts of the country where enforcement is sought may have to assess the scope of the order and limit its territorial reach or its impact on third parties. In the Internet era, recourse to global injunctions may create risks of inadequately prohibiting certain activities that can be legal if limited to the territory of a given country. ${ }^{37}$ Because of the territorial nature of intellectual property rights, offering a product protected by intellectual property for sale or making it available for download on the Internet might be legal in some countries of reception but not in others. Under these circumstances, a court's injunction must only encompass the illicit part of the behaviour, and the infringer must be allowed to continue his legal Internet activities or be able to adapt his Internet presence without the right holder having the possibility to prevent him from doing so on the basis of the original judgment. In case of relief concerning Internet activities, it may be especially important to safeguard the interests of third parties in foreign countries who can be affected by the

${ }^{36}$ As to the grant of injunctions against alleged patent infringements in the U.S., see $e$ Bay Inc. $v$. MercExchange, LLC, 546 U.S. 1029 (2005), and Benjamin Petersen, 'Injunctive Relief in the Post-eBay World', (2008) 23 Berkeley Tech. L.J. 194.

37 James J Fawcett and Paul Torremans, Intellectual Property and Private International Law (2nd edn, 2011) para 19.63. 
enforcement of the order in certain situations, as illustrated by the notorious German decision in the Hotel Maritime case concerning trademark use in Internet activities. ${ }^{38}$

In the context of Internet activities, there is an increasing recourse to injunctions against intermediaries. Even in situations in which intermediaries may not be held liable, they may be required by a court to terminate or prevent an infringement. Among the most popular injunctions in this context are those ordering to block access to foreign websites involved in infringement activities ${ }^{39}$, such as those adopted in EU countries on the basis of national legislation implementing article 8(3) of the Infosoc Directive ${ }^{40}$. Although such orders usually have international applications and are intended to block access to websites located abroad, recognition and enforcement abroad is usually not necessary in these cases, since the orders are typically addressed to intermediaries located in the jurisdiction of the rendering court.

Nonappearance by the defendant should not prevent a court to adjudicate a dispute. Therefore, although the recognition and enforcement of foreign default judgments may raise some special difficulties and needs, it is widely accepted that such judgments are subject to recognition and enforcement. In the European context, concerning recognition of default judgments, the focus rests on the verification by the requested court of the respect in the court of origin of the rights of defence of the defendant by proper summons in adequate time ${ }^{41}$. This requirement is intended to guarantee adequate protection of defaulting defendants and is closely connected to the procedural public policy clause. Therefore, recognition of foreign default judgments is affirmed in situations in which the defendant was duly serviced of the document instituting the proceedings and had the opportunity to present his case. From a broader comparative

\footnotetext{
${ }^{38}$ Bundesgerichtshof Judgment of 13.10.2004, JZ, 2005 at 736-738.

${ }^{39}$ See, e.g., Martin Husovec, "Injunctions against Innocent Third Parties: The case of Website Blocking”, (2012) 4 JIPITEC, 2, , 116-129.

${ }^{40}$ Article 8(3) Directive 2001/29/EC of 22 May 2001 on the harmonisation of certain aspects of copyright and related rights in the information society (OJ 2001 L 167/10) ("Member States shall ensure that right holders are in a position to apply for an injunction against intermediaries whose services are used by a third party to infringe a copyright or related right”). Also see Article 11 Directive 2004/48/EC of 29 April 2004 on the enforcement of intellectual property rights (OJ 2004 L 157/45).

${ }^{41}$ This approach is also common to many national, regional and international instruments, see, e.g., Article 34(2) Brussels I Regulation and Lugano Convention, Article 9(c)(i) Hague Convention on Choice of Court Agreements of 2005, and, in the US, Section 4(c)(1) Uniform Foreign-Country Money Judgments Recognition Act (2005).
} 
perspective, the possibility to recognize and enforce foreign default judgments relating to intellectual property matters is also the prevailing trend, even if the checks applied to those judgments may differ. For instance, in case of default judgments the ALI Principles require verifying that the rendering court's assertion of personal jurisdiction was consistent with the law of the state of origin (§ 402 ALI Principles). By contrast, the CLIP Principles do not impose such an additional requirement, in line with the position prevailing in domestic systems and international conventions that do not impose review based on the application of the jurisdictional rules of the rendering state.

\section{Provisional measures}

Enforceability of foreign provisional measures is typically refused in all those systems that restrict such possibility to decisions being final or non-appealable in the country where they were rendered. The basic rationale underlying this approach is that enforceability of such foreign measures may create particular risks, due to the interim nature of such measures, which may later be revoked and which can be based on an alleged infringement that may be found to be non-existent. Therefore, a restrictive approach prevails in many national regimes and international conventions, that do not allow for recognition of enforcement of provisional measures. Notwithstanding this, the current trend to facilitate cross-border enforcement of provisional measures is of particular importance with regard to intellectual property litigation, due to the practical significance of interim relief in this context.

The EU regime allows recognition and enforcement of foreign provisional measures, although with some restrictions that apply to these judgments in addition to the common grounds to refuse recognition and enforcement. First, it differentiates between measures adopted by a court having jurisdiction over the merits and those ordered by other courts. The latter are excluded from recognition and enforcement. Provisional measures adopted by a court not having jurisdiction as to the substance cannot be recognised or enforced in other Member States. The new Article 2(a) of the Brussels recast confirms this situation, by stating that for the purposes of recognition and enforcement, the term “judgment” includes provisional measures ordered by a court that has jurisdiction under 
the Regulation as to the substance of the matter ${ }^{42}$. Other provisional measures do not benefit from the enforcement mechanism under the Regulation and typically they do not produce effects outside the territory of the court that grants the measures. A second traditional restriction in the EU regime excluded ex parte provisional measures from recognition and enforcement in other Member States ${ }^{43}$. Under the new Brussels recast, a more liberal approach is introduced. Pursuant to Article 2(a) Regulation (UE) No. $1215 / 2012$, even provisional measures adopted without the defendant being summoned to appear may be recognized and enforceable, provided that the judgment containing the measure is served on the defendant prior to enforcement. ${ }^{44}$ Such a development is consistent with Directive 2004/48/EC on the enforcement of intellectual property rights. As already noted, the EU regime only applies to the reciprocal recognition and enforcement of judgments between EU Member States.

The acceptance that provisional measures may be recognised and enforced abroad subject to certain limitations is a common feature of the recent proposals for legislative reform in this field. The CLIP Principles establish similar restrictions as those existing under the Brussels system. In particular, according to Article 4:301(2) CLIP Principles, provisional and protective measures adopted without prior hearing of the adverse party and enforceable without prior service of process to that party shall not be recognized or enforced. This restriction is aimed at ensuring adequate protection to the rights of the defendant in a global context. Although Article 50(2) TRIPS Agreement establishes that courts shall have the authority to adopt provisional measures inaudita altera parte where appropriate, it does not impose on contracting states an obligation to recognize foreign decisions adopted under these circumstances.

By contrast to the CLIP Principles, the ALI Principles do not expressly exclude the recognition and enforcement of ex parte provisional measures. Notwithstanding this, the practical results may be similar in both projects. Ex parte provisional measures are

\footnotetext{
${ }^{42}$ A similar approach may be found in the EU instruments on unitary industrial property rights, in particular in Article 103(2) Regulation (EC) No 207/2009 of 26 February 2009 on Community trade marks and Article 90 Regulation (EC) No 6/2002 of 12 December 2001 on Community designs.

43 ECJ 21 May 1980, Case 125/79, Denilauler, [1980] ECR 1553, para 18.

${ }^{44}$ Christian Heinze, 'Choice of Court Agreements, Coordination of Proceedings and Provisional Measures in the Reform of the Brussels I Regulation’, (2011) 75RabelsZ, pp. 581-618 at 615.
} 
subject to the application of the grounds of non-recognition and enforcement established in $\S 403$ (1)(a)-(d) ALI Principles, that are intended to ensure the respect of procedural guarantees, including proper and timely notice and an opportunity to be heard.

\section{Grounds for non-recognition}

\section{A. General considerations}

A basic feature of every system of recognition and enforcement is the determination of the grounds for non-recognition. This choice establishes the relevant checks to control foreign judgments. The comparison between the national systems of recognition and enforcement shows significant differences in this regard. However, common approaches as to the basic elements of an appropriate model for recognition and enforcement concerning intellectual property matters, may be derived from the similarities between the several model provisions drafted recently in this area. In order to establish a balanced recognition and enforcement regime concerning intellectual property litigation it seems appropriate to establish an exhaustive list of refusal grounds and to disregard certain refusal grounds that traditionally have played a significant role in some national systems ${ }^{45}$.

For instance, a specific requirement concerning the application by the court of origin of the same law that would have been applicable according to the private international law of the requested state, seems particularly inappropriate in the context of intellectual property litigation. The abandonment of such a control is in line with the modern international trend of focusing on the verification of jurisdiction and not allowing a scrutiny of the law applied by the rendering court, this being true especially in instruments not dealing with family matters or the status of natural persons. Furthermore, reciprocity as a condition for recognition and enforcement concerning intellectual property disputes between private parties seems especially inappropriate in the current context of an expansion of individual rights and greater interdependence between countries. The application of reciprocity to the recognition and enforcement of

\footnotetext{
${ }^{45}$ See Pedro A. De Miguel Asensio, supra, note 1, with references.
} 
foreign judgments in civil and commercial matters has been subject to intense criticism as inappropriate and unfair ${ }^{46}$. The refusal to give effect to a foreign judgment in these matters solely on the basis of a lack of reciprocity with the state of origin and as a means of retaliating against it or pressing it to change its law, may raise even significant human rights concerns, due to the negative implications on the rights of persons involved in private litigation. The recognition of foreign judgments in civil and commercial matters concern the interests, rights and duties of the private parties involved and hence should be regarded primarily as a private matter. The interests involved are different from those prevailing in public law matters, such as international cooperation in tax law or criminal prosecution. In litigation on civil and commercial matters, including intellectual property, the approach should prevail that a judgment otherwise entitled to recognition will not be denied recognition on the ground that the rendering country might not recognise a judgment of the country where recognition is sought if the circumstances were reversed.

Possible grounds to refuse recognition and enforcement fall mainly within four categories: verification of the jurisdiction of the rendering court to adjudicate the relevant case; safeguard of the procedural guaranties of the party against whom recognition or enforcement is sought; protection of substantive public law; and irreconcilability with another judgment or prior pending proceedings ${ }^{47}$. In principle, there is no distinction in this regard between recognition and declaration of enforceability of foreign judgments, since the same requirements apply to both except for the one concerning the enforceability of the judgment in the country of origin that only applies when enforcement is sought. The idea that a substantive review of a foreign judgment is not possible in the framework of recognition and enforcement is common to almost all international, regional, and national systems of recognition and enforcement.

\section{B. Verification of Jurisdiction}

${ }^{46}$ Although the issue remains highly controversial in many jurisdictions, see e.g. Katherine R. Miller, 'Playground Politics: Assessing the Wisdom of Writing a Reciprocity Requirement into U.S. International Recognition and Enforcement Law’, (2004) 35 Geo. J. Int’ L. 239, 299.

${ }^{47}$ See Pedro A. De Miguel Asensio, supra, note 1, with references. 
This ground for non-recognition allows the requested court to review whether the original court exercised jurisdiction in a manner considered appropriate in the recognizing country. It makes possible to assess the existence of a sufficient link between the dispute concerned and the State where the adjudicating court sat that is also of great importance in guaranteeing an adequate protection for the defendant. This control is needed to ensure the respect to the exclusive jurisdiction rules of the requested State and to guarantee that judgments based on exorbitant grounds of jurisdiction in situations in which the country of origin has no relevant connection with the dispute shall not be recognized. Therefore, some grounds of jurisdiction used in certain systems are typically not acceptable when exorbitant. Examples may be jurisdiction founded solely on the document instituting the proceedings having been served on the defendant during his temporary presence in the rendering country, or jurisdiction based only in the presence within the country of origin of property belonging to the defendant not directly related to the dispute.

As to the relevant standard of review, in the absence of international conventions or regional instruments, many national systems rely on the so-called mirror-image approach. Pursuant to this approach, judgments can only be recognized if they were given by a court that founded its jurisdiction on a ground existing also in the requested State. A more flexible approach, favouring recognition and enforcement, seems preferable. In this respect, the standard of equivalence approach, considers acceptable for recognition judgments rendered by a court of a country having a connection with the dispute equivalent to those established in the jurisdiction rules of the requested State, even if not formally identical, provided that a significant connection exists between the rendering country and the dispute.

From an international perspective, it can be noted that the development of uniform instruments may be particularly relevant to favour recognition by providing further predictability as to the application of this ground for non-recognition. In particular, socalled double conventions include provisions on (direct) jurisdiction coupled with rules on recognition and enforcement. Mixed conventions establish grounds of jurisdiction that are acceptable for recognition purposes in all member states and grounds of 
jurisdiction that are prohibited, giving member states freedom to decide on recognition of judgments based on grounds of jurisdiction other than those expressly admitted or prohibited. Under pure double instruments member states are required to adopt certain grounds of jurisdiction, and to the extent that the rendering court based its jurisdiction on any of those grounds, it is to be considered that the original court's jurisdiction meets the standards required for its recognition and enforcement in other member states. Hence, in that kind of instrument, unification of jurisdiction provisions among member states decisively influences the jurisdiction review in the recognition stage. The Brussels I Regulation rests on this approach.

Since judgments that conflict with the exclusive jurisdiction provisions of the requested State cannot be recognized or enforced, the interpretation and scope of the exclusive jurisdiction rules are decisive not only directly to allocate competence to the courts but also indirectly, because due to their mandatory character they may decisively influence non-recognition of foreign judgments. For instance, in the application of the Brussels system within the EU, verification of the jurisdiction of the rendering court is possible if the foreign judgment conflicts with the exclusive jurisdiction rules of the Brussels I Regulation. Therefore, the reach of the possible review is influenced by the scope of article 22.4 of the Brussels I Regulation (art. 24.4 recast) ${ }^{48}$. In this connection, it is relevant that the ECJ held that proceedings relating to the validity, existence, or lapse of a patent or an alleged right of priority by reason of an earlier deposit are to be regarded as proceedings "concerned with the registration or validity of patents" for the purposes of establishing exclusive jurisdiction. By contrast, when the dispute does not itself concern the validity or the existence of the deposit or registration, there is no special reason to confer exclusive jurisdiction ${ }^{49}$. Therefore, not all disputes that may result in decisions that can be the basis for changes in the records of the registries of a state fall within the exclusive jurisdiction. Judgments on some of those issues may not be concerned with the registration, grant, or the validity of the intellectual property right as such. Only judgments that interfere in the functioning or operation of the public registry

${ }^{48}$ See, in particular, ECJ Judgments of 13 July 2006, C-4/03, GAT/LuK, [2006] ECR I-6509; 13 July 2006, C-539/03, Roche Nederland, [2006] ECR I-6535 and 12 July 2012, C-616/10, Solvay, [2012] ECR I-0000(nyr).

${ }^{49}$ ECJ Judgment of 15 November 1983, 288/82, Duijnstee, [1983] ECR 3663, paras. 23-25. 
may be deemed to have as their object the registration of the right. To the extent that neither the validity of the intellectual property right nor the legality of its registration are disputed by the parties, the claim does not fall within the scope of the exclusive jurisdiction. ${ }^{50}$ Therefore, a foreign judgment on the entitlement or the ownership of an intellectual property right subject to registration does not conflict with the exclusive jurisdiction.

Additionally, the trend to further restrict the reach of exclusive jurisdiction in intellectual property litigation is of great importance in this context ${ }^{51}$. Article 4:202 CLIP Principles illustrates the potential implications of this approach to favour crossborder recognition and enforcement of judgments. Article 4:202 establishes that recognition and enforcement of a foreign judgment may not be refused on the ground that in the proceedings before the court of origin the validity or registration of an intellectual property right registered in a state other than the state of origin was challenged, provided that the recognition and enforcement produces effects only between the parties. This approach, related to the progressive jurisdiction provisions on validity of the CLIP Principles, facilitates the adjudication before the courts of a single country of infringement claims in cases in which validity is incidentally challenged, because it makes possible the cross-border enforcement of decisions rendered in these situations. A similar provision may be found in section 413(2) ALI Principles.

\section{Procedural guarantees}

Public policy as a ground for non-recognition has a procedural dimension. In fact, some international conventions and national legislations concerning recognition and enforcement contain separate references to substantive and procedural public policy. The latter is intended to safeguard that the specific foreign proceedings leading to the judgment were not manifestly incompatible with fundamental principles of procedural fairness of the requested state. In Europe the development of common standards as to

${ }^{50} \mathrm{Ibid}$, paras. 26-27, stressing the distinction between disputes concerning the right to a patent (not falling within the exclusive jurisdiction of Article 22.4 of the Brussels I Regulation) and disputes concerning the registration or validity of a patent which are covered by the exclusive jurisdiction.

${ }^{51}$ See Benedetta Ubertazzi, Exclusive Jurisdiction in Intellectual Property Mohr Siebeck (2012), p. 218. 
the right of fair trial under Article 6 European Convention on Human Rights (ECHR) and the Charter of Fundamental Rights ${ }^{52}$ has important consequences in the area of recognition and enforcement of judgments. A contracting state of the ECHR may infringe Article 6 by enforcing a foreign judgment that has been obtained in conditions which constitute a breach of that Article. In light of the case law of the European Court of Human Rights (ECtHR), the right to a fair trial under Article 6.1 ECHR demands a review of whether the proceedings before the foreign court that rendered the judgment which is to be recognized fulfilled the guarantees of Article $6^{53}$. The ECJ when applying Article 34(1) Brussels I Regulation has acknowledged that in determining procedural public policy, guidance is to be found in the jurisprudence of the ECtHR.

From an international perspective, fundamental principles of procedural fairness may comprise: basic standards of independence and impartiality of the court; procedural equality of the parties; due notice and the right to be heard; the right of the parties to engage a lawyer; a reasoned explanation of the essential basis of the judgment; and prompt rendition of justice. However, the consequences and restrictions resulting from these principles and their interpretation may vary significantly between different legal systems. With respect to intellectual property litigation it is noteworthy that Part III TRIPS Agreement has been the basis for an important approximation of national procedural laws regarding the means of enforcing intellectual property rights. TRIPS is a source of international standards implemented in the legislation of the contracting states that may contribute to reducing the number of situations in which procedural public policy is an obstacle to recognition and enforcement in IP litigation. For instance, Article 42 TRIPS Agreement lists some basic features that civil procedures concerning the enforcement of IP rights must have in order to qualify as fair and equitable. These include the right of defendants to timely and written notice containing sufficient detail; the possibility of the parties of being represented by independent legal counsel; the avoidance of overly burdensome requirements concerning mandatory personal

52 Charter of Fundamental Rights of the European Union [2007] OJ C303/1.

53 See ECtHR, Pellegrini v. Italy, Judgment of 20 July 2001, Case no 30882/96 para. 40; and Saccoccia v. Austria, Judgment of 18 December 2008, Case no 69917/01 para. 62, available at www.echr.coe.int. 
appearances; and the right of the parties to substantiate their claims and to present all relevant evidence.

Because of the exceptional nature of public policy, the existence of differences between the procedural law of the country of origin and that of the requested country is not determinative to refuse enforcement inasmuch as such differences do not decisively affect in the case concerned fundamental procedural fairness and do not undermine essential principles of the system in which enforcement is sought. In this respect, significant differences may be found between common law systems and civil law systems, but they may not affect fundamental principles of procedural fairness, to the extent that the legal systems involved provide sufficient guarantees for a fair and impartial trial. For example, it seems appropriate to consider that a civil judgment based on a jury verdict should not in principle be regarded as contrary to public policy in countries that do not use civil juries. Also, differences with respect to the availability of discovery devices between the country of origin and the requested country should not be an obstacle to the enforcement of the judgment.

\section{Substantive public policy}

As construed in most recent international conventions, regional instruments and national legislations, substantive public policy leads to the refusal of recognition and enforcement of a foreign judgment to the extent that it would be manifestly incompatible with the public policy of the requested state. Therefore, the application of public policy as a ground for non-recognition is limited to situations in which the violation can be easily ascertained by the requested court. It is an exceptional device to be applied only in very limited situations, where the extension of the relevant judgment effects to the requested country openly undermines the fundamental principles and basic values of its legal order ${ }^{54}$. Hence, recognition is not to be refused on the sole ground that the court of origin applied a law other than that which would have been applicable under the private international law of the state in which recognition is sought.

\footnotetext{
${ }^{54}$ Marketa Trimble Landova, 'Public Policy Exception and Enforcement of Judgments in Cases of Copyright Infringement’, (2009) 40 IIC, issue 6, pp. 642-665.
} 
Additionaly, mere differences in substantive law do not give rise to a manifest incompatibility with the essential fundamental principles and values of the requested state. In the European Union, the ECJ has also considered that discrepancies between the country of origin and the enforcing country as to the subject matter that may be protected by intellectual property rights do not allow recourse to the clause on public policy of the Brussels I Regulation unless the differences amount to a manifest breach of a fundamental principle of the legal order of the country in which enforcement is sought ${ }^{55}$.

Although public policy is typically a national defense, based on the basic values and fundamental principles of a national legal system, the exceptional nature of the substantive public policy defense in intellectual property litigation must be reaffirmed based on the significant level of international harmonization in this field, resulting mainly from the TRIPS Agreement and the conventions administered by WIPO ${ }^{56}$. Additionally, religious differences do not have such a strong impact on the structure and basic principles of intellectual property litigation as in family law and other areas of the law. For instance, with respect to Islamic law, the prevailing view is that there is no serious conflict between the principles and objectives of Shari'a and modern mechanisms for protecting intellectual property as presented in international treaties.

Notwithstanding the degree of international harmonization achieved in this field, intellectual property disputes may affect significant public interests in sensitive areas in which basic values differ across different jurisdictions. For instance, scope of patent protection may have strong consequences on the availability of products necessary to meet health and safety needs. Restrictions on the patentability of bio-technological inventions are usually intended to safeguard human dignity and additional ethical values. This may lead to refuse the enforcement of a foreign judgment concerning the protection of bio-technological inventions that are regarded as contrary to such basic values of the country in which enforcement is sought. The mandatory nature of moral rights of authors may also be an obstacle to the enforcement in some countries of

\footnotetext{
55 ECJ 11 May 2000, Case C-38/98, Renault, [2000] E.C.R. I-2973, paras. 30-34.

${ }^{56}$ See Pedro A. De Miguel Asensio, supra, note 1, with references.
} 
foreign judgments disregarding such rights. Also, cultural policies may be deeply influenced by copyright protection. Given the connection of the territorial nature of intellectual property rights with the public policies involved in the protection of intellectual property, recourse to public policy may be justified for refusing recognition of a judgment in some exceptional situations in which territoriality has been clearly disregarded by the court of origin. However, in most situations in which such court acted in disregard of the territorial restrictions of intellectual property rights, recourse to other mechanisms shall suffice. In particular, the possibility to narrowly interpret the territorial scope of injunctions and of refusing recognition as a result of the verification of the jurisdiction of the rendering court may be relevant for these purposes.

Interaction between some fundamental rights and intellectual property protection may also raise difficulties as to the application of public policy to the extent that such fundamental rights vary across nations. In the US, Sarl Louise Ferand Int'l $v$. Viewfinder $^{57}$ illustrates how competing interests between the copyright laws and the rights protected by the First Amendment in the U.S. may also raise public policy concerns. The decision of the Court of Appeal offers an example of some of the consequences of the restrictive and exceptional nature of public policy. In particular, the Court of Appeal noted that the fact that the foreign judgment found copyright infringement under foreign law on a subject matter that is not copyrightable in the U.S. does not make the foreign judgment contrary to public policy ${ }^{58}$.

In the EU, the interface between intellectual property protection and other fundamental rights has received particular attention in the recent case-law of the $\mathrm{ECJ}^{59}$. These judgments illustrate how important is that the protection of the right to intellectual property must be balanced against the protection of other fundamental rights of individuals who are affected by the measures aimed at protecting copyright holders. With regard to the limits of injunctions requiring hosting service providers and Internet

57 Sarl Louis Feraud Int'l v. Viewfinder, Inc., 406 F. Supp. 2d 274, 285 (S.D.N.Y. 2005), vacated, 489 F.3d 474 (2d Cir. 2007).

${ }^{58}$ Viewfinder, 489 F.3d at 480 n.3.

59 See ECJ Judgment of 24 November 2011, C-70/10, Scarlet Extended, [2012] ECDR 4; ECJ Judgment of 16 February 2012, C-360/10, SABAM, [2012] 2 CMLR 18; and ECJ Judgment of 19 April 2012, C-461/10, Bonnier Audio, [2012] 2 CMLR 42. 
access providers to instal filtering systems with a view to protect intellectual property, the ECJ has stressed the need to strike a fair balance between the right to intellectual property, on the one hand, and the freedom to conduct business, the right to protection of personal data and the freedom to receive or impart information, on the other. The balancing between the competing interests arising out of the protection of intellectual property, on the one hand, and freedom of expression under Article $10 \mathrm{ECHR}$, including the fundamental right to receive and depart information, on the other, also has been of particular importance in the recent case-law of the ECtHR regarding the enforcement of intellectual property to Internet activities and the margin of appreciation open to the domestic authorities when balancing those interests ${ }^{60}$.

Courts in civil law countries and other jurisdictions have traditionally considered that recognition of foreign awards imposing punitive damages may be in contradiction with public policy. However, a trend can be identified towards the introduction in these systems of a flexible approach that may facilitate under certain circumstances the (partial) recognition and enforcement of foreign judgments imposing punitive damages. This trend is also favoured by the restrictions on non-compensatory damages implemented in some countries having such a category of damages, that has contributed to a reduction of the gap with other legal systems. Furthermore, in many countries whose liability system is compensatory and where punitive damages are alien to the domestic legal system, damages may cover non-monetary damage, statutory damages are now being introduced and institutions may be found in which civil liability rules have additional functions beyond compensation. Moreover, in civil law jurisdictions, the costs associated with litigation are commonly awarded to the successful claimant. Hence, it may happen that the amount of punitive damages awarded by a US court does not always so grossly exceed the amount a court would grant a plaintiff in the same dispute in a country where punitive damages are not known.

${ }^{60}$ See ECtHR Judgment of 10 January 2013, Ashby Donald and Others v. France, no 36769/08, concerning the conviction of fashion photographers for copyright infringement following the publication on the Internet site of photos taken at fashion shows; and 19 February 2013 (decision on the admissibility), Neij and Sunde Kolmisoppi v. Sweden, no. 40397/12, concerning the inadmissibility of the complaint by two of the co-founders of one of the world's largest websites for sharing files, that their conviction for complicity to commit crimes in violation of the Copyright Act had breached their freedom of expression. 
In this context, an international trend to restrict recourse to public policy as a reason not to recognise foreign judgments that award non-compensatory damages is gaining importance. This development led to the adoption of a compromise provision in Article 11 of the 2005 Hague Convention on Choice of Court Agreements. In the field of intellectual property litigation, this provision has been used as a blueprint in Section 411 ALI Principles and Article 4:402 CLIP Principles. Under this restrictive approach, recognition of a judgment may be refused if, and only to the extent that, the judgment awards damages, including punitive damages, that do not compensate a party for actual loss or harm suffered, and exceed the amount of damages that could have been awarded by the courts of the requested State (including costs and expenses relating to the proceedings).

\section{Declaration of enforceability and enforcement measures}

Recognition basically refers to an extension of the legal effects the foreign judgment produces in the country of origin. By contrast, enforcement requires that the courts of the requested State adopt the necessary measures to give one party the relief granted to it by the foreign judgment, having recourse to public coercive force when needed. Although, recognition of foreign judgments by operation of the law and without any special procedure being required is possible under many international conventions, regional instruments and national legislations, enforcement is typically subject to a previous specific procedure to obtain a declaration of enforceability in the enforcing country, usually known as exequatur. Once a foreign judgment has been declared enforceable in the country of destination, its enforcement is usually governed by the same rules that apply to the enforcement of domestic judgments.

International conventions usually do not address the procedural aspects of the declaration of enforceability of a foreign judgment and leave these issues to the law of the enforcing country. In Europe one of the main goals of the reform of the Brussels I Regulation has been to abolish within the EU the need to bring specific proceedings intended to obtain a declaration of enforceability of a judgment from another Member 
State. The issues raised by the abolition of exequatur are not specific to judgments arising out of intellectual property disputes, but this development will significantly affect the enforcement of judgments in this field.

The Brussels I recast makes possible to proceed directly to the enforcement in other Member States of a judgment which is enforceable in the Member State of origin without any declaration of enforceability being required. Judgments given by the courts of a Member State are to be treated as if they had been rendered in the Member State addressed. Moreover, the new Regulation establishes in Annex I a model certificate that has to be served on the person against whom enforcement is sought in reasonable time before the first enforcement measure. Such model certificate with all relevant information about the judgment will facilitate the cross-border enforcement of judgments within the EU. Notwithstanding this, the safeguards implemented in the new system have finally restricted the transformation resulting from the abolition of exequatur ${ }^{61}$. The Regulation gives to the person against whom enforcement is sought the possibility to apply for the refusal of the enforcement to the competent court of the Member State where enforcement is sought. Enforcement will be refused where one of the grounds for refusal of recognition or enforcement set out in Article 45 is found to exist. Those grounds apply in addition to the grounds for refusal or of suspension of enforcement under the law of the Member State addressed for judgments rendered by its own courts.

To assess the limited progress achieved by the new Regulation it is noteworthy that the grounds to refuse enforcement under Regulation 1215/2012 (art. 45) are the same

61 Therefore, the situation under the Brussels I recast differs from other previous Regulations abolishing exequatur that do not retain the public policy clause, such as the provision on child abduction and visits of Regulation (EC) No 2201/2003 of 27 November 2003 concerning jurisdiction and the recognition and enforcement of judgments in matrimonial matters and the matters of parental responsibility (OJ 2003 L 338), Regulation (EC) No 805/2004 of 21 April 2004 creating a European Enforcement Order for uncontested claims (OJ 2004 L 143) or Regulation (EC) No 861/2007 of 11 July 2007 establishing a European Small Claims Procedure (OJ 2007 L 199). The ECtHR in its Judgment Povse v. Austria of 18 June 2013, no 3890/11 (para. 86), held that the duty of the Austrian courts pursuant to Regulation (EC) No 2201/2003 to enforce an Italian order without any scrutiny as to its merits would not deprive the party against whom enforcement was sought of any protection of their Convention rights; in particular, since it was open to that party to rely on their Convention rights before the courts of the country of origin. However, the approach finally adopted in the Brussels I recast, while abolishing exequatur, envisages further controls in the enforcing State. 
provided for by Regulation 44/2001 to deny exequatur (arts. 34 and 35). The exhaustive list of checks include public policy, respect of the rights of defence of the defaulting defendant, incompatibility between judgments, and very limited verification of the jurisdiction of the rendering court. Therefore, the grounds to refuse enforcement remain unchanged and the main progress refers to a procedural development. Since the need for a special procedure (exequatur) is abolished, the control now takes place directly in the framework of the enforcement itself by enabling the party against whom enforcement is sought to bring an application for the refusal of the enforcement. Such an application may deeply affect enforcement, since the court in the Member State addressed may: limit the enforcement proceedings to protective measures; make enforcement conditional on the provision of security; or suspend the enforcement proceedings. Moreover, pursuant to article 47 Brussels I recast, without prejudice to the provisions of the Regulation, the procedure for refusal of enforcement shall be governed by the law of the Member State addressed.

The basic rule is that once the foreign judgment becomes enforceable in the requested state, it is incorporated into its legal order and has to be treated as a judgment of the requested state. Therefore, the law of the enforcing country applies to the execution process. The procedural law of the enforcing country determines issues such as: organs of enforcement, including the judicial or administrative nature of enforcement; grounds for refusing enforcement ${ }^{62}$; modes of enforcing money and non-money judgments; and even methods of coercion and sanctions for non-compliance. Methods of enforcement are generally determined by the law of the requested state. Regarding non-money judgments and injunctions in particular, this can pose specific difficulties ${ }^{63}$. The rendering court may have ordered in the judgment specific measures intended to ensure enforcement in case of non-compliance, such as penalty payments in favour of public authorities $^{64}$ or even imprisonment, and the claimant may request their enforcement in

${ }^{62}$ In the particular context of the Brussels I recast, pursuant to Article 41(2), the grounds for refusal or of suspension of enforcement under the law of the Member State addressed shall apply in so far as they are not incompatible with the grounds for refusal of recognition referred to in Article 45.

63 See, e.g., Marketa Trimble, Global Patents (Limits of Transnational Enforcement) OUP (2012) p. 167.

64 Given that the measures ordered may be unknown in the requested state, the determination of the rules of procedure that the national court has to apply to enforce the foreign order may become a significant obstacle; for instance, concerning the enforcement in The Netherlands of a German decision 
the requested country. In these cases, to the extent that the available methods of enforcement are different in the rendering state and the enforcing state, significant uncertainties may appear.

Cases where the type of relief granted or the coercive measures envisaged in the foreign judgment are unknown or are not available in the country where recognition or enforcement is sought deserve careful consideration. In these situations, when the foreign judgment fulfils the conditions necessary for its recognition in the requested state, it seems appropriate to grant a remedy available in the enforcing country that is functionally or substantially equivalent to the one awarded in the foreign judgment ${ }^{65}$. This approach has now been confirmed by Article 54 Brussels I recast. According to this provision, if a judgment contains a measure or an order which is not known in the law of the Member State addressed, that measure or order shall, to the extent possible, be adapted to a measure or an order known in the law of that Member State which has equivalent effects attached to it and which pursues similar aims and interests. Any party may challenge the adaptation of the measure or order before a court.

on patent infringement that pursuant to § 890 of the German Civil Procedure Code (Zivilprozessordnung, ZPO) imposed on the infringer a fine to be payable to the public authorities for breach of a prohibition order, see ECJ, Judgment of 18 October 2011, C-406/09 Realchemie Nederland, [2012] Bus. L.R. 1825; [2012] C.E.C. 449; [2012] I.L.Pr. 1, para 43.

${ }_{65}$ Concerning the cross-border enforcement in the EU of a periodic penalty payment coupled to a prohibition order against the infringement of a trade mark and stating that the obligation of the court of the country where enforcement is sought is to 'attain the objective pursued by the measure by having recourse to the relevant provisions of its national law which are such as to ensure that the prohibition originally issued is complied with in an equivalent manner', see ECJ Case C-235/09 DHL Express France $v$ Chronopost, [2011] ETMR 33, para 56. 